\title{
The Influence of Employer Branding Towards Generation Z Students Attractiveness on Start-up Unicorn
}

\author{
Adelia Shabrina Prameka ${ }^{\mathrm{a}, *}$, Abdullah Sanusi ${ }^{\mathrm{b}}$, Ooji Futari II ${ }^{\mathrm{a}}$, Yesiana Ihda Kusnayain ${ }^{\mathrm{a}}$ \\ ${ }^{a}$ Departement of Management, Faculty of Economics, Universitas Negeri Malang, Indonesia \\ ${ }^{b}$ Departement of Management, Faculty of Economics and Business, Universitas Hasanuddin Makassar, Indonesia
}

\begin{abstract}
The development of the world revolution has changed the paradigm and stigmas of organizational quality to increase competitiveness from various human resource perspectives. Increasing global challenges have made the employer branding strategy a concern for global research. This study examines the effect of employer branding on Generation Z students' attractiveness and employer choices at unicorn start-ups in Indonesia. This study uses the Structural Equation Model Partial Least Square (SEM-PLS). This study got a total of 200 respondents who fit the criteria. This study's dimensions of employer branding are work culture, ethics CSR, diversity, and salary incentives. From the results of this study, the dimensions that proved to be influential were Ethics and CSR, and Diversity. Besides, work culture and salary incentives are not proven to significantly affect the attractiveness of Generation $\mathrm{Z}$ students to Indonesian unicorn start-ups. Social media is proven to have a significant effect on both attractiveness and choice of the workplace (employer of choice) Generation Z students at Indonesian unicorn start-ups
\end{abstract}

Keywords: employer branding, Generation Z, start-up unicorn, employer of choice

\section{INTRODUCTION}

In today's increasingly competitive era, companies are required to have a competitive strategy that can improve quality and competitive advantage. Competition is not just about getting consumers; competition in getting employees with high capabilities is one form of competition in increasing the company's value. One challenge that companies have to face in the labor market today is attracting potential talents by creating employer branding (Figurska and Matuska, 2013). The company believes that capable employees can raise the prestige of the company itself. One strategy to increase competitive advantage is the optimization of employer of choice with employer branding (Sivertzen et al., 2013). The concept of employer branding is like a brand image in a marketing science that can position the company in the minds of potential employees (Berthon et al., 2005). Employer branding is one way to attract talented people to join the organization and ensure that potential employees and organizations have the conformity of vision to provide results that meet expectations (Lindholm, 2018). This form of strategy

\footnotetext{
*Author in correspondence,

Email address: adelian.shabrina.fe@um.ac.id (Adelia Shabrina Prameka)
}

ISSN: 2549-3221 (Print) 2549-323X (Online)

DOI: $10.26487 /$ hebr.v5i2.2910 is to develop a more specific value proposition and promotion in internal and external companies (Lievens, 2007) such as offers and promises (Sivertzen et al., 2013).

In this period, humans are categorized into a generational group. These generations are organized by year of birth in each group, from generations $\mathrm{X}, \mathrm{Y}$, and $\mathrm{Z}$ to alpha generation. Generation $\mathrm{Z}$ ranks first in Indonesia and the world and is currently at the peak of productive age. Generation $\mathrm{Z}$ group was born in 1995 to 2009 (Herman and Gioia, 2000). According to a report from IDN.times (2020) titled Indonesian Millennial 2020 report show that Millennials and Generation $Z$ have characteristics that freedom soul, multitasking, and technological literacy. Although Generation $\mathrm{Z}$ has unique features, according to a survey from Deloitte entitled "The Deloitte Global Millennial Survey 2020 Resilient generations hold the key to creating a "better normal" as much as $69 \%$ of Generation $\mathrm{Z}$ is able to provide a favorable work ecosystem, and $71 \%$ is able to have a positive impact in the community so that the company is able to work well. Besides, millennials have high loyalty accompanied by a supportive environment (Deloitte, 2020).

Technological advances are directly proportional to the advancement of science. Various new companies appeared in the field of technology, one of which is start-ups. A start-up is a start-up or a company that has not been operating for a long time. Start-ups are human institutions designed to create products or services amid extreme uncertainty. Start-up companies 
created new ideas in controlling the world's electronics business (Yusuf et al., 2020). The pace of technological innovation has a boost from two sides, namely demand and supply. The demand side is caused by increasing global competition, while scientific breakthroughs cause the supply side

\section{LITERATURE REVIEW}

\subsection{Employer Branding}

The brand is the most valuable asset for a company, and as a result, brand management becomes an essential activity in most companies (Backhaus and Tikoo, 2004). In addition to companies focused on developing their brand through product development and corporate brand, branding can also be used in human resource management or known as "employer branding" (Backhaus and Tikoo, 2004). Employer branding is a process in building the company's identity through employees and prospective employees to distinguish the company from its competitors (Sivertzen et al., 2013). Based on a conference board report (Backhaus and Tikoo, 2004). companies that make effective employer branding will make the company have a competitive advantage, and help employees internalize the company's value, and help in suppressing the amount of turnover. In building employer branding, there are three processes: developing the concept of value proposition, external bidding process, and thirdly making the brand's promise through internal and organizational culture.

\subsection{Unicorn Start-up}

The term Unicorn is taken from a mythological horse species that has a single horn on its head. In awarding their titles to a start-up, unicorns represent the fairytale horse's status: rare and impossible or challenging to achieve. The term was first introduced by Cowboy Ventures founding investor Aileen Lee in her article "Welcome to The Unicorn Club," published in TechCrunch in 2013 (Yusuf et al., 2020). Unicorns can attract foreign capital into the country and bring a positive impact in the Indonesian economy. Foreign capital invested in unicorns in Indonesia is not concerned that foreigners will dominate one day because foreign capital flows in the early years of unicorn companies' operation. Indonesia will be one of the drivers of economic growth and depending on the state budget, domestic investment, and income from the export side. Furthermore, unicorns can have a multiplier impact on economic growth and equality, such as providing jobs and the absorption of mass employment, so that the unemployment rate will be significantly reduced. The presence of unicorns is also able to accelerate the flow of distribution of goods and services from Brodersen to consumers and able to empower people towards economic independence (Yusuf et al., 2020).

\subsection{Employer of choice}

Employer of Choice (EOC) is an organization that has an appeal that can inspire individuals to join and survive in a company. EOC is an organization that employees choose for reference to work (Herman and Gioia, 2000). The Attraction Selection Attrition (ASA) model states that individuals tend to be attracted to similar value organizations and will persist and contribute to the organization (Schneider, 1987). EOC is one way to increase the value of prepositions and also create a brand image of an organization (Marginingsih et al., 2017). So EOC is one of the strategies to attract potential and talented employees to join the company. Therefore, the need to build credibility and proper value to attract potential employees through the EOC. From an organizational point of view, this assessment is explained in the concept of person organizational fit. Employees are more interested in organizations that have a match and similarity with the expected value so that the existence of an organizational fit person can provide the tendency of employees to survive and contribute. So, the employer of choice plays a vital role in helping potential employees choose the right company

\section{RESEARCH METHODS}

The data analysis method in this study is Structural Equation Model Partial Least Square (SEM-PLS). Unlike COVARIANCE Based SEM which is a lot of name names, SEM-PLS can be used when it is a small sample. Moreover, the employer branding research model;

1. $H_{1 a}$ : Work Culture positively influence the Organizational Attractiveness

2. $H_{1 b}$ : Diversity positively influence the Organizational Attractiveness

3. $H_{1 c}$ : Ethics and CSR positively influence the Organizational Attractiveness

4. $H_{1 d}$ : Salary Incentives positively influence the Organizational Attractiveness

5. $\mathrm{H}_{2}$ : Social Media positively influence the Organizational Attractiveness

6. $H_{3}$ : Social Media positively influence the Employer of Choice

7. $H_{4}$ : Organizational attractiveness positively influences the Employer of Choice

\section{Measurement}

Variable measurement items for employer branding and employer of choice using items from Tanwar and Kumar (2019) is based on the most recent research. The items used to measure Social media are developed by Collins and Han (2004) and used in (Roper et al., 2013). The entire measurement scale uses a 6Likert scale with a value of 1 for "Strongly Disagree" and 6 for "Disagree". 


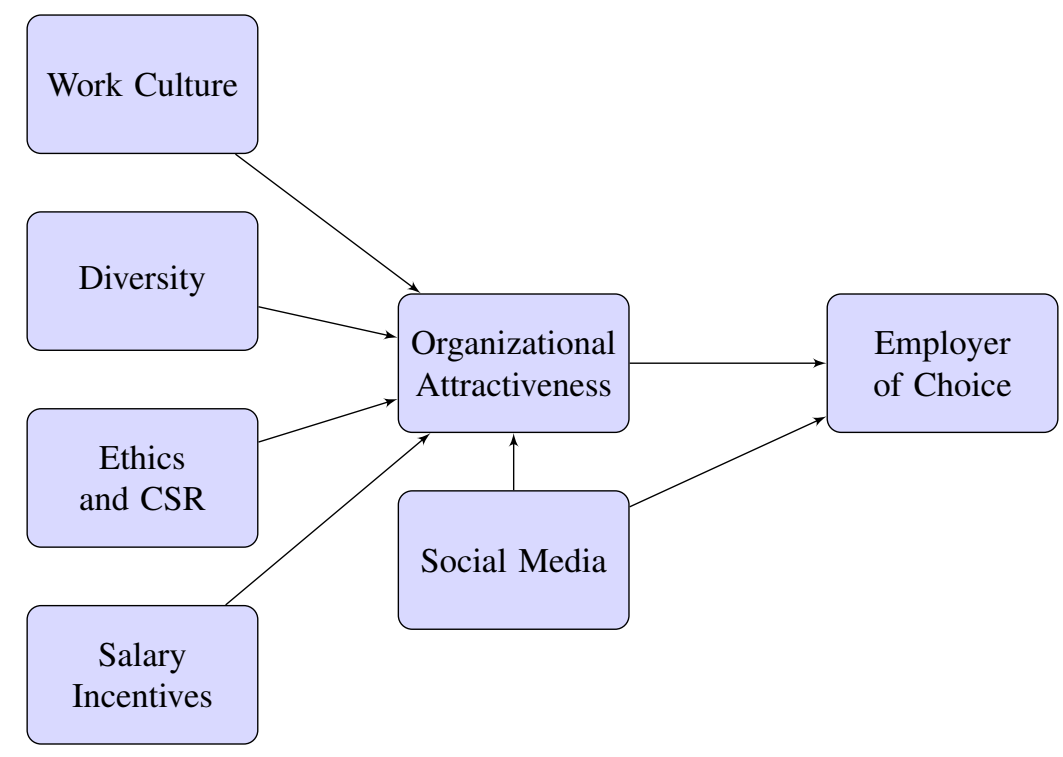

Figure 1: Research Model

\section{RESULTS AND DISCUSSION}

\subsection{Results}

\subsubsection{Respondent Demographics}

Respondents in this study were students of Universitas Negeri Malang. Madden literature (2017) explains that Generation Z comprises people aged 17 to 22 years. Before processing the data, questionnaires have been distributed to respondents with a total of 240 people. This method is only related to students aged 17 to 22 years, then only 200 people were sampled, consisting of 59 male students and the remaining 41 female students. Questionnaires have also been filled out honestly and entirely following the questions in the questionnaire.

\subsubsection{Data Analysis}

Research using PLS-SEM is divided into two stages, namely outer model analysis and Inner Model. The outer model analysis consists of checks on item validity, internal consistency, Averaged Variance Extracted (AVE), and discriminant validity. Furthermore, the item validity can be seen through the loading factor value. The loading factor value 0.7 is said to be ideal, and the item is declared valid. Internal consistency evaluation is seen from composite reliability (CR) and Cronbach Alpha values. The AVE value used in this study was a minimum of 0.5 , which indicates convergent validity. The CR and Cronbach Alpha limit values are 0.7 . Discriminate validity is using the evaluation of cross-loading on each latent variable.

\subsubsection{Validity Test}

Validity test in this study using outer loading indicator with a standard value of 0.7 . From the results of data processing conducted found three items have a value below 0.7 , namely two items of work culture, namely WC3 and WC6 with outer loading values of 0.630 and 0.625 respectively, D4 items in diversity with outer loading value of 0.634, and E2 items on Ethics CSR with outer loading of 0.649. All four items will be removed from the model because they are declared invalid.

\subsubsection{Reliability Test}

According to the reliability tests, variables work culture, ethics and CSR, diversity, salary and incentives, organizational attractiveness, employer choice, and social media. All variables are reliable based on Cronbach Alpha, Composite Reliability, and Average Variance Extracted (AVE) values. Questionnaire variables are said to be reliable when the CR and Cronbach Alpha limit values are 0.7 and AVE values 0.5 so, it can be concluded that those variables are reliable and shown in the Table 1 .

Table 1: Cronbach's Alpha, CR, and AVE

\begin{tabular}{|c|c|c|c|}
\hline & $\begin{array}{l}\text { Cronbach's } \\
\text { Alpha }\end{array}$ & $\begin{array}{l}\text { Composite } \\
\text { Reliabil- } \\
\text { ity (CR) }\end{array}$ & $\begin{array}{l}\text { Average } \\
\text { Vari- } \\
\text { ance } \\
\text { Ex- } \\
\text { tracted } \\
\text { (AVE) }\end{array}$ \\
\hline Employer of Choice & 0,942 & 0,963 & 0,896 \\
\hline $\begin{array}{l}\text { Organizational } \\
\text { Attractiveness }\end{array}$ & 0.782 & 0.875 & 0.702 \\
\hline Social Media & 0.810 & 0.885 & 0.720 \\
\hline Work Culture & 0.831 & 0.875 & 0.541 \\
\hline Diversity & 0.743 & 0.839 & 0.568 \\
\hline Ethics and CSR & 0.790 & 0.863 & 0.615 \\
\hline Salary and Incentives & 0.873 & 0.913 & 0.725 \\
\hline
\end{tabular}

\subsubsection{Descriptive Statistics}

The average value of work culture, ethics and CSR, diversity, salary and incentives, organizational attractiveness, em- 
ployer of choice, and social media variables and shown in the following table below. The statistics Descriptive has been illustrated in Table 2.

Table 2: Descriptive Statistics

\begin{tabular}{lll}
\hline & Mean & SD \\
\hline Diversity & 47.152 & 0.7620 \\
Employer of Choice & 4.0151 & 11.451 \\
Ethics and CSR & 46.365 & 0.8118 \\
Organizational Attractiveness & 45.712 & 0.7838 \\
Salary and Incentives & 46.193 & 0.8191 \\
Sosial Media & 44.439 & 0.9260 \\
Work Culture & 45.678 & 0.8256 \\
\hline
\end{tabular}

\subsubsection{Hypotheses testing}

Based on data processing from SmartPLS, this study confirms that work culture and salary incentives are not proven to affect organizational attractiveness.

The $\mathrm{p}$-value is greater than 0.05 with t-statistics values at 1,692 and 1,464, respectively, so that the H1a and H1d hypotheses are rejected. Besides, diversification and ethics CSR significantly affect organizational attractiveness where the $\mathrm{p}$-value is less than 0.05 with t-statistics values at 4,537 and 3,003, respectively. Therefore, the $H_{1} a$ and $H_{1} b$ hypotheses are accepted.

For testing the $\mathrm{H}_{2}$ hypothesis, which tests the relationship of social media to organizational attractiveness, the analysis results showed that social media proved to have a significant influence on organizational attractiveness. This is based on a significance value of 0.002 (p-value0.05: t-statistics=3.137). It is also shown in the social media related to employers of choice who have a value of 0.000 (p-value 0.05: t-statistics $=6.195)$. The results confirm a significant link between social media and employer of choice so that the $\mathrm{H} 3$ hypothesis is accepted. In the last hypothesis test, the $\mathrm{H} 4$ hypothesis also showed the same result, where the value of significance was 0.000 (p-value 0.05: t-statistics $=5,701$ ) so that the $\mathrm{H} 4$ hypothesis was accepted. The study also showed that organizational attractiveness towards employers of choice.

Indirect relationship testing showed that organizational attractiveness proves to mediate the influence of diversification on employers of choice (Table 4) with p-value values smaller than 0.05 (t-statistics $=3.392$ ). In addition, organizational attractiveness is proven to mediate the influence of ethics; CSR on employers of choice with $\mathrm{p}$-value values smaller than 0.05 (tstatistics $=2.554$ ). Lastly, organizational attractiveness is also proven to act as a mediation variable in social media's influence against employers of choice with p-value values smaller than 0.05 (t-statistics $=2.797)$.

\subsection{Discussion}

The data analysis results showed that work culture variables have no effect on organizational attractiveness variables on Generation Z students' Attractiveness at Unicorn Start-up. The results can be caused if the student respondent does not have enough knowledge and information related to the work culture at Start-up Unicorn because the organizational culture is only known after working for the company. Moreover, the majority of respondents are in the East Java area, which allows them not to have enough information and knowledge related to the working culture of Start-up Unicorn. Most unicorn start-up companies have offices in Jakarta.

Two dimensions of employer branding are: (1) Ethics CSR; (2) diversity has a significant effect on the Organizational Attractiveness of Generation Z students at Start-up Unicorn. CSR activities can be a means to develop and implement elements of employer brand in an economic, functional, and psychological (Lindholm, 2018). Generation $\mathrm{Z}$ is usually very concerned about the activities of companies that have an impact on society. It depicts a Generation $\mathrm{Z}$ character who is typically loyal, thoughtful, open-minded, an agent of change, and making a difference Miraja et al. (2019). CSR is often the company's way of informing when the company is not only focused on business and profit but cares about the community and the environment.

Salary Incentives turned out to have no significant effect on Generation Z students' Attractiveness to Unicorn Start-ups. This is not in line with previous research that showed economic aspects as essential factors for organizational Attractiveness and the reason for joining a company (Jiang and Iles, 2011). On economic value and "well-being and remuneration", they evaluated whether employers provided more than average salary, reward packages, job guarantees, and promotional opportunities (Lee et al., 2018).

In this study, social media significantly influenced the Attractiveness and decision to choose a Unicorn Start-up for Generation $\mathrm{Z}$ students. When organizations use social media to attract prospective employees, it must be seen concerning potential job seekers' desire to apply for jobs (Cappelli, 2001). Companies can focus on organizational attributes (employer branding dimensions) that are considered important as employers for practical tools on social media in recruitment and strengthening employer brands (Roper et al., 2013).

Organizational Attractiveness has a significant influence on choosing (employer choice) Generation Z students at Start-up Unicorn. Interest in companies often leads them to struggle to join. The decision to join was driven by the suitability of Generation Z with the company's value.

\section{CONCLUSION}

Based on this study's results, it can be concluded that there is an influence of employer branding on the attractiveness of Generation $\mathrm{Z}$ students in Indonesian unicorn start-ups. The dimension that proved influential is Ethics and CSR and Diversity. In addition, Salary incentives have not been proven to significantly affect the attractiveness of Generation $\mathrm{Z}$ students in Indonesian unicorn start-ups. Social media in this study showed a crucial role where social media proved to have a significant influence on both the attractiveness and choice of employers of choice of Generation Z students at Indonesian unicorn start-ups. The organization's attractiveness is also able to play a role in 
Table 3: Cross Loadings

\begin{tabular}{lrrrrrrr}
\hline & $\mathbf{1}$ & $\mathbf{2}$ & $\mathbf{3}$ & \multicolumn{1}{c}{$\mathbf{4}$} & \multicolumn{1}{c}{$\mathbf{5}$} & $\mathbf{6}$ & $\mathbf{7}$ \\
\hline Diversity & 1,000 & 0.45 & 0.55 & 0.68 & 0.56 & 0.47 & 0.53 \\
Employer of Choice & 0.45 & 1,000 & 0.44 & 0.62 & 0.46 & 0.65 & 0.38 \\
Ethics and CSR & 0.55 & 0.44 & 1,000 & 0.66 & 0.74 & 0.41 & 0.67 \\
Organizational Attractiveness & 0.68 & 0.62 & 0.66 & 1,000 & 0.65 & 0.54 & 0.6 \\
Salary and Incentives & 0.56 & 0.46 & 0.74 & 0.65 & 1,000 & 0.51 & 0.65 \\
Sosial Media & 0.47 & 0.65 & 0.41 & 0.54 & 0.51 & 1.000 & 0.41 \\
Work Culture & 0.53 & 0.38 & 0.67 & 0.6 & 0.65 & 0.41 & 1.000 \\
\hline
\end{tabular}

Source: Research Computation

Table 4: Hypotheses Testing

\begin{tabular}{lccc}
\hline & $\begin{array}{c}\text { Standard } \\
\text { Deviation }\end{array}$ & t-Statistics & p-values \\
\hline WC $->$ OA $->$ EC & 0.023 & 1,589 & 0.113 \\
DIV $->$ OA $->$ EC & 0.037 & 3,392 & 0.001 \\
CSR $->$ OA $->$ EC & 0.034 & 2,554 & 0.011 \\
SI $>$ OA $->$ EC & 0.035 & 1.449 & 0.148 \\
SM $->$ OA $->$ EC & 0.023 & 2.797 & 0.005 \\
\hline
\end{tabular}

Source: Research Computation

encouraging the selection of workplaces (employer of choice) in Indonesian unicorn start-ups.

\section{References}

Backhaus, K., Tikoo, S., 2004. Conceptualizing and researching employer branding. Career Development International.

URL: https://www.emerald.com/insight/content/doi/10.1108/ 13620430410550754/full/html

Berthon, P., Ewing, M., Hah, L. L., 2005. Captivating company: dimensions of attractiveness in employer branding. International Journal of Advertising 24 (2), 151-172.

URL: https://doi.org/10.1080/02650487.2005.11072912

Cappelli, P., 2001. Making the most of on-line recruiting. Harvard Business Review, March.

Collins, C. J., Han, J., 2004. Exploring applicant pool quantity and quality: the effects of early recruitment practice strategies, corporate advertising, and firm reputation. Personnel Psychology 57 (3), 685-717.

URL: https://onlinelibrary.wiley.com/doi/10.1111/j. 1744-6570.2004.00004.x

Deloitte, 2020. The Deloitte Global Millennial Survey 2020.

URL: https://www2.deloitte.com/content/dam/ Deloitte/global/Documents/About-Deloitte/ deloitte-2020-millennial-survey.pdf

Figurska, I., Matuska, E., 2013. Employer Branding As a Human Resources Management Strategy. In Human Resources Management \& Ergonomics (Vol. 7.

URL: http://www.randstadaward.ca

Herman, R. E., Gioia, J. L., 2000. How to Become an Employer of Choice. Oak Hill Publishing Company, Naperville, IL.

URL: https://onlinelibrary.wiley.com/doi/pdf/10.1002/ert. 1015
Jiang, T., Iles, P., 2011. Employer-brand equity, organizational attractiveness and talent management in the Zhejiang private sector, China. Journal of Technology Management in China 6 (1), 97-110.

URL: https://www.emerald.com/insight/content/doi/10.1108/ $17468771111105686 / \mathrm{full} / \mathrm{html}$

Lee, C. C., Kao, R. H., Lin, C. J., 2018. A study on the factors to measure employer brand: the case of undergraduate senior students. Chinese Management Studies.

Lievens, F., 2007. Employer branding in the Belgian army: the importance of instrumental and symbolic beliefs for potential applicants, actual applicants, and military employees. Human Resource Management 46 (1), 51-69. URL: https://onlinelibrary.wiley.com/doi/10.1002/hrm. 20145

Lindholm, L., 2018. The use of corporate social responsibility in employer branding. Developing Insights on Branding in the B2B Context 2, 73-93. URL: https ://doi.org/10.1108/978-1-78756-275-220181005

Marginingsih, R., Darmajaya, J. B., Marginingsih, R., 2017. Kepemimpinan Karismatik Sebagai Employer Branding. Jurnal Bisnis Darmajaya 2 (2), $32-51$.

URL: https://jurnal.darmajaya.ac.id/index.php/ JurnalBisnis/article/view/706

Miraja, B. A., Persada, S. F., Prasetyo, Y. T., Belgiawan, P. F., Redi, A. A. N.P., 2019. Applying protection motivation theory to understand Generation $\mathrm{Z}$ students intention to comply with educational software anti piracy law. International Journal of Emerging Technologies in Learning 14 (18), 39-53. URL: https://online-journals .org/index.php/i-jet/article/ view/10973

Roper, S., de Carvalho, L. V., Guzman, F., Sivertzen, A.-M., Nilsen, E. R., Olafsen, A. H., 2013. Employer branding: employer attractiveness and the use of social media. Journal of Product \& Brand Management. URL: https://doi .org/10.1108/JPBM-09-2013-0393

Schneider, B., 1987. The people make the place. PersonnelPsychology 40 (3), $437-453$.

Sivertzen, A.-M., Nilsen, E., Olafsen, A., 10 2013. Employer branding: Employer attractiveness and the use of social media. Journal of Product and Brand Management 22.

URL: https://doi.org/10.1108/JPBM-09-2013-0393

DOI: $10.1108 /$ JPBM-09-2013-0393

Tanwar, K., Kumar, A., 2019. Employer brand, person-organisation fit and employer of choice.

DOI: $10.1108 / \mathrm{pr}-10-2017-0299$

Yusuf, Y. M., Prastyo, D. A., Khaerunnisa, L., Raharjo, S. T., 2020. Implementasi Program Corporate Social Responsibility Oleh Perusahaan Unicorn Di Indonesia. Prosiding Penelitian Dan Pengabdian Kepada Masyarakat 6 (3), 252.

URL: https://doi.org/10.24198/jppm.v6i3.26214 